\title{
CORRESPONDENCE
}

\section{Hoyle on life}

SIR - Surely there is some mistake in your summary of Hoyle's contention that the Universe has not been here long enough to permit the evolution of life forms of the complexity found on this planet (Nature 12 November, p.105).

It is true that the probability of chance assembly of the system of genes upon which our life system depends is very low. However, it is not this particular probability which is relevant, but rather the result of multiplying this admittedly small number with the very large number representing the total number of gene systems which could also be the basis for complex life forms.

Any particular gene possesses its enzymatic properties as the result of its configuration in some quite small part of its total chain length. Although the chance of random assembly of the total chain, specified at every point, is small, the chance of assembly of a gene specified over a small fraction of its length is obviously much larger.

If you modify your account of Hoyle's arguments along these lines, I suggest you will conclude that we are all here after all.

British National Oil Corporation (Development) Limited, Glasgow, UK

\section{Postdocs in Canada}

SIR - I would like to pass on some news that I have just obtained with regard to the status of foreign postdoctoral fellows working in Canada. The Canadian Immigration Regulations require that before a foreigner can be of fered employment, the position must be advertised through Canada Employment Centres, and suitably qualified nationals must be given preference. This regulation does not apply to postdoctoral fellows, but Canadian officials both in London, England and in Toronto assured my wife and myself that it did apply to their spouses. When we came to Canada last year my wife was unable to find a job, and since postdocs in biological sciences are not well paid (see Nature 11 June and 8 October), it became necessary for my wife to return to England to work.

This seemed an unfair system, so I brought it to the attention of Lloyd Axworthy, the Canadian Minister of Employment and Immigration. I have received a reply from him to the effect that since such restrictions do not apply to Canadian postdocs going to work in Britain, Canada is prepared, in this case, to reciprocate. $\mathrm{He}$ is instructing all Canadian immigration of ficials that this is now the case. So in the future, married postdocs will be able to move between both countries without facing financial hardship. However, it is implied that this relaxation does not apply to individuals from countries which do not already show hospitality to Canadians. I am impressed by the fact that the experience of an individual can successfully modify governmental regulations, but surely it is opportune, and for the mutual benefit of all concerned, for all countries which wish to foster academic exchange to take steps to relax immigration rules for the families of postdoctoral fellows.

DYlan EDWARDS

The University of Western Ontario,

London, Canada

\section{Open relations}

SIR - Your article about the agreement between this hospital and the international chemical company Hoechst AG (Nature 5 November, p.5) states that the Government Accounting Office forced open the contract heretofore kept from Congressman Albert Gore. In fact, Massachusetts General Hospital gave the document to Congressman Gore on 21 July 1981

What we did in October was to make the contract available to the general public from whom we have had a number of requests. In fact, we know of no other instance in which such a contract has been made available to the public. We have taken this course because we are presenting the agreement to our external Scientific Advisory Committee this month. The committee's topic, scheduled many months ago, is scientific relations with industry.

Massachusetts General Hospital,

Boston, Massachusetts, USA.

\section{Life out there}

\section{SIR - It was interesting to read in} juxtaposition Dr Zuckerman's review of the extraterrestrial issue and Professor O'Neill's review of Rood and Trefill's new book on the same subject (Nature 5 November, pp.10, 25) One is struck again by the fascination - not to say fixation - that earlier and "young revolutionary" students of this issue have had with technology as an index of "advanced" civilization. The idea that other planets may have chosen to focus on spiritual rather than technical development dates back to at least the eighteenth century polymath Swedenborg. As is often noted nowadays, the validity of technology - rather than, say, spirituality as an index of cultural achievement is less than clear even for our own globe. It seems premature to disregard the Drake (or Green Bank) equation simply due to lack of verification of its technology/colonization components. What is called for instead, perhaps, is greater conceptual bandwidth in its formulation.

KURT SimONS

Wills Eye Hospital,

Philadelphia, Pennsylvania, USA

\section{Leave links open}

SIR - Dorothy Hirsch, Executive Director of the Committee for Concerned Scientists, ended her eloquent letter (Nature 13 August, p.578) about the plight of Soviet scientists with the charge to us that "We cannot afford to become hardened to the plight of oppressed colleagues who have much to contribute to a vital international science". Time $(28$ September) reports that exiled Soviet writers, despite enormous grievances against the Soviet government, have pleaded that free world publishers should not boycott the Moscow International Book Fair which means so much to the ordinary Russian citizen as well as the Russian literati. I have just returned from an international medical/scientific congress in Moscow, and wish to make a similar appeal to Western scientific groups resolved to boycott all scientific interchanges hosted by the Soviets.

At that congress 1 concluded my scientific presentation with a slide listing a dozen of the Soviet scientists sentenced to "internal exile" (imprisonment) for their dissident views, and stated simply that my presentation was dedicated to "these fellow scientists in the sincere hope thay they may be free again some day soon to join with their colleagues from other nations in open scientific interchanges such as this one'". It is still tearful for me to recall the response of the stony-faced Russian scientists in the audience to that statement. Almost in unison, they lowered their eyes, nodded very slightly, and a whispered chorus of "Da! Da! Da!" ("Yes! Yes! Yes!') filled that Moscow meeting room.

I appeal to individuals and scientific societies that have decided to boycott Soviethosted scientific interchanges as a protest that they reconsider their decision. Boycotts do little to embarrass or punish the Soviet government for its repressive and reprehensible policies towards dissident scientists (writers, intellectuals, etc.); attendance at these scientific interchanges as representatives of free world countries may do much to assure the Russian scientific/ academic community of our awareness of their plight, and of our deep concern and sympathy for them. It lets them know of our resolve not to cut them off from new information from the outside world, but to share with them our scientific findings, our ideas, our literature, which they, like us, should not be denied. They are obviously not optimistic that things will change in the near future. Let us at least continue to help them endure what they must so that they can continue with their careers, with their scientific research which they love as much as we do.

LEE FRANK

Department of Medicine,

University of Miami, School of Medicine, Miami, Florida, USA

\section{Not cricket either}

SIR - Certainly the City of New York's Yankees deserve numerous boos and catcalls for their performance in the World Series. Just as certainly, your publication deserves similar treatment for printing a column ("Shame on New York", Nature 5 November, p.2) demonstrating both little understanding of the subject and a shameful neglect of facts evident to all but the most illiterate American youth.

You state "Part of the reason why the Yankees lost is that they were not as skilled at catching and throwing the ball as were the Dodgers", a glaring misstatement in light of the Dodgers' second baseman's infamous accumulation of six World Series records for "errors committed" (literally: failure to catch and throw the ball). In addition, claiming that there was "little to choose between the batting performance of the two teams" ignores the dismal failure of one of the Yankees' most depended-upon batters (Dave Winfield, playing under a multi-million dollar contract) to connect for more than one hit in twenty-two at bats during the series.

Concerns for propriety and my own temperament forbid me to further chronicle and refute the errors contained within the column. Allow me to end my tirade by pointing out your insensitivity in measuring the speed of a baseball in units of "metres per second" thereby violating the worshipful reputation of baseball as "a game of inches". The Salk Institute,

Peter Syka 